\title{
PEMENUHAN HAK KESEHATAN REPRODUKSI NAPI PEREMPUAN DI LEMBAGA PERMASYARAKATAN (LAPAS) PROVINSI RIAU
}

\author{
Achmad Hidir \\ Rr Sri Kartikowati \\ Universitas Riau \\ E-mail: hidir09@yahoo.com ; tiko22@yahoo.com
}

\begin{abstract}
It is suspected that there is a potential human rights abused against woman prisoner's reproductive health in Riau Province's prisons. This research aims to identify human rights abused related woman prisoner's reproductive health and found the affort to reduce it. The methods used to collect the data are interviews, documentation and observation. While Focus Group Discussion (FGD) conducted as part of the analysis stage interactive model (Miles and Huberman). The results showed that there is a potential human rights abused related to woman prisoner's reproductive health in Riau Province prisons. It is occurred because of limited prison infrastructure, including getting access to goods essential needs during menstruation like pads. Efforts to reduce human rights abused against women prisoners in the prisons while improving compliance and protection of human rights is conducting the capacity building for the staff of prisons, setting clear standards compliance for the health rights of women prisoners, operating system of evaluation and monitoring of the implementation of the health right, adding women prisons officers, and build prisons that were intended for female inmates.
\end{abstract}

Kata Kunci: narapidana (napi) perempuan, Hak Asasi Manusia (HAM), pelanggaran 


\section{PENDAHULUAN}

Ranah kriminlitas tidak selalu didominasi oleh kaum laki-laki. Buktinya perempuan kerap diberitakan melakukan tindak kejahatan. Akibatnya, para perempuan tersebut juga menjadi penghuni penjara atau Lembaga Pemasyarakatan (LAPAS) dengan berbagai sebab. Menurut $M$. Adib, keterlibatan perempuan dalam ranah kriminalitas tersebut bisa jadi disebabkan oleh kondisi masyarakat yang semakin modern dimana kesenjangan sosial semakin terlihat dan semakin kompleks; dan akibat selanjutnya muncul perilaku menyimpang (faktor kriminogen) yang semakin luas di dalam masyarakat. ${ }^{1}$

Selain itu, perempuan seringkali terjebak ke dalam keadaan yang kurang menguntungkan bagi dirinya. Mereka dijadikan budak nafsu atau sebagai alat untuk perdagangan narkotika, yang mau tidak mau akhirnya menggiring mereka pada situasi kejahatan dan untuk kemudian berurusan dengan pihak berwajib yang berakhir di dalam sel penjara. ${ }^{2}$

Dari penjabaran di atas dapat diketahui bahwa para perempuan berurusan dengan penjara karena beberapa alasan, seperti karena kesulitan ekonomi, karena lemahnya iman dan kontrol sosial, dan bisa jadi karena lingkungan sosial yang tidak mendukung sehingga para napi perempuan tersebut menghuni LAPAS. Dalam konteks tersebut studi ini ditekankan pada bagaimana posisi kaum perempuan yang telah bertindak criminal, yang kini menjadi narapidana menghuni Lembaga Pemasyarakatan (LAPAS) menjalani kehidupan mereka, dari perspektif hak untuk kesehatan.

Sebagai individu, napi perempuan memiliki kebutuhkan untuk mengekspresikan kemanusiaannya, baik berupa hasrat biologis, religius, dan sosial. Sayangnya, kondisi mereka yang tengah terbelenggu oleh aturan LAPAS mengakibatkan mereka tidak bebas lagi mengekspresikan berbagai hasrat tersebut, padahal prinsip-prinsip dasar perlakuan bagi para napi menyatakan bahwa semua napi harus diperlakukan dengan rasa hormat atas kehormatan yang melekat pada diri mereka dan nilainilainya sebagai manusia. ${ }^{3}$ Misalnya, perempuan dengan kodratnya memiliki fungsi reproduksi yang berbeda dengan kaun laki-laki. Siklus reproduksi kaum perempuan cukup panjang dan rumit yang dimulai dari masa pra-pubertas, pubertas, menstruasi, reproduksi, pra-menopause, menopause, pasca-menopause, coforo-pause, prasenium, dan senium ${ }^{4}$.

Siklus reproduksi yang dialami perempuan ini adalah hal yang wajar, namun dapat menjadi tidak wajar apabila perempuan yang sedang 
menjalani kodratnya ini mengalami hambatan karena situasi lingkungan di dalam penjara sehingga tidak mendapat perlakuan atau akses kesehatan yang berkurang. Faktor sanitasi, kebersihan pakaian dalam, dan perawatan "nyeri haid" menjadi sangat penting atas kekhawatiran terkena penyakit infeksi saluran reproduksi bagi mereka. ${ }^{5}$

Kota Pekanbaru dan Bengkalis sebagai dua kota yang mewakili propinsi Riau menerima titipan khusus napi perempuan. Di dua lokasi LAPAS ini, berdasarkan data pendahuluan, diduga terjadi pelanggaran hak azasi mereka. Di LAPAS Pekanbaru, napi perempuan tidak menempati Blok terpisah khusus untuk napi perempuan, melainkan mereka menempati lokasi yang digabungkan antara Blok perempuan dewasa dan Blok Anak. Kabupaten Bengkalis juga tidak memiliki LAPAS khusus perempuan. Para napi perempuan ditempatkan bersebelahan dengan napi laki-laki dewasa, yang hanya dipisahkan dengan kawat tinggi. Ketika napi perempuan akan keluar LAPAS, mereka harus melewati area yang juga dilalui oleh napi laki-laki. Mereka ditempatkan dalam sel tahanan yang luasnya tidak memadai. Saat ini kondisi semua blok dalam keadaan daya tampung yang melebihi daya tampung atau over capacity.

Realita yang terjadi di LAPAS Pekanbaru dan Bengkalis di atas memberi benang merah tentang potensi terjadinya pelanggaran HAM dan bagaimana mereka diperlakukan di dalam LAPAS. Untuk mengetahui hal tersebut lebih jauh, penelitian ini mengkaji dua hal, yaitu mengidentifikasi pelanggaran HAM bagi napi perempuan terutama dalam ketersediaan sarana fisik dan lingkungan, serta hak akses atas kesehatan (reproduksi); dan mengkaji upaya mengurangi pelanggaran HAM napi perempuan tersebut.

Riset ini menggunakan paradigm fenomenologis yang memfokuskan pada analisis pemahaman (emic view) atas respon dan perilaku para napi perempuan di dalam LAPAS antara sesama napi perempuan dan napi dengan petugas LAPAS.

Sejumlah langkah dilakukan untuk memperoleh data dan menganalisisnya. Data dihasilkan dalam bentuk deskriptif yang berasal dari subyek yang diteliti (emic) melalui wawancara kepada narasumber utama - narapindana perempuan. Bila dimungkinkan telah dilakukan wawancara mendalam sebagai upaya menggali lebih jauh dan mencapai akurasi data tentang inti persepsi mereka sendiri atas pemenuhan akses kesehatan (reproduksi).

Kedua, dilakukan intepretasi (etic) atas hasil wawancara untuk dituangkan dalam bentuk draft laporan penelitian. Ketiga, karena laporan 
penelitian tersebut masih dalam bentuk data mentah, langkah selanjutnya adalah melaksanakan FGD (Focus Group Discussion) dengan tujuan membuka wacana lebih luas, terbuka, dan terarah hingga mencapai jawaban masalah penelitian. Anggota peserta FGD adalah para napi perempuan, petugas LAPAS, dan peneliti).

Perlu dinyatakan bahwa penelitian adalah instrumen utama penelitian. Proses analisis sebenarnya telah dilakukan sejak awal bersamaan dengan pengumpulan data, dan seiring perolehan data yang semakin banyak, maka digunakan analisis dengan pendekatan dialogical interpretation model analisis interaktif (Miles dan Huberman); dan teknik triagulasi data berdasarkan sumber yang berbeda. Tiga langkah analisis berisi data reduction, data display, dan verification $\&$ conclusion.

\section{HASIL PENELITIAN DAN PEMBAHASAN}

Untuk menjawab pertanyaaan penelitan pertama, mengenai identifikasi pelanggaran hak azasi manusia bagi napi perempuan, dalam konteks hak untuk kesehatan telah dilakukan diskusi. Diskusi dimulai dari aturan atas Hak bagi narapidana dengan merujuk pada Undangundang RI nomor 12/1995, tentang Sistem Pemasyarakatan, Pasal 14 (ayat 1). Kemudian Fokus Group Discussion (FGD) menyoroti bentuk-bentuk pelanggaran HAM bagi napi perempuan yang mungkin ada dan terjadi di dalam kehidupan di LAPAS. Temuan tersebut lalu dianalisis untuk menemukan cara menekan terjadinya pelanggaran HAM dan menemukan upaya-upaya pemenuhan Hak atas kesehatan bagi napi perempuan, dan mempromosikan nilai-nilai HAM dalam kehidupan di dalam LAPAS. Berikut ini adalah penjelasannya.

\section{Napi Perempuan dan Hak atas Kesehatan}

Di dalam LAPAS, semua narapidana (napi) diperlakukan seperti layaknya masyarakat pada umumnya yang memiliki hak asasi sesuai prinsip-prinsip demokrasi dan anti-diskriminasi. LAPAS menyediakan fasilitas-fasilitas fisik dan berusaha memenuhi kebutuhan napi, termasuk pemenuhan kebebasan beribadah, fasilitas kesehatan, pendidikan dan kebutuhan utama lainnya. Fasilitas tersebut merupakan hak napi sebagai warga binaan LAPAS. Semua pemenuhan hak-hak napi sebagaimana diamanatkan dalam Undang-undang RI No 12 tahun 1995, tentang Sistem Pemasyarakatan, Pasal 14 (ayat 1) tentang jaminan hak-hak para narapidana.

Selanjutnya, kondisi di dalam LAPAS dapat ditelusuri menurut teori supply and demand (hukum permintaan dan penawaran). Ketika 
permintaan meningkat maka penawaran akan meningkat pula; dan ketika penawaran meningkat, maka harga (price) pun akan tinggi.

Smelser (1987) dalam Sosiologi Ekonomi menyatakan supply and demand dalam hubungannya dengan faktor lain selalu menjadi variabel berpengaruh (dependent variables). Berarti, pengekangan kebebasan dalam suatu pemenjaraan akan berdampak pada hubungan sosiologis antara petugas (yang powerful) dan penghuni penjara (yang powerless). Hubungan kekuasaan yang tidak seimbang ini akan menumbuhkan konflik laten dan terus menerus dalam sebuah sistem sosial masyarakat di dalam LAPAS. Akibatnya, apabila muncul suatu konflik, keberadaan suatu sistem, konsekuensinya, akan menciptakan mekanisme untuk meredam konflik tersebut, sehingga tidak ada dampak destruktif terhadap sistem. Mekanisme tersebut dalam sosiologi disebut proses akomodasi, yakni suatu upaya meredam konflik melalui tukar-menukar kepentingan diantara dua kubu yang mengalami konflik.

Dalam kondisi inilah, fungsi penjara (LAPAS) dapat diharapkan sebagai tempat untuk mengubah tingkah laku penghuninya (para napi) dari yang tidak baik menjadi perilaku yang terpuji. Secara faktual, kondisi ideal tersebut sering kali sulit dicapai, karena berbagai alasan. Bisa disebutkan beberapa alasan, antara lain, karena rendahnya kualitas dan kesejahteraan petugas cenderung menciptakan penyimpangan kewenangan (abuse by power). Hal ini akan semakin parah ketika seorang napi memiliki status sosial ekonomi yang lebih tinggi dari petugas LAPAS. Akibatnya muncul situasi tawar menawar dalam praktek negosiasi.

\section{Ketersediaan Pembalut untuk Perempuan}

Karena setiap napi perempuan memiliki tingkat status yang berbeda, setidaknya ada tiga pola besar bagaimana napi perempuan mendapatkan kebutuhan pembalut bulanannya. Pertama, tergantung dari tingkat kedekatan hubungan sangat baik dengan petugas LAPAS; kedua, tergantung dari lamanya napi telah menghuni LAPAS; dan ketiga, tergantung pada kunjungan rutin keluarga napi ke LAPAS.

Dari tiga pola tersebut, data lapangan menjumpai rincian pola cara perolehan pembalut perempuan, sebagai berikut:

Tabel I

Cara Napi Perempuan Mendapatkan Pembalut

\begin{tabular}{|c|c|c|}
\hline No & Item & $0 \%$ \\
\hline
\end{tabular}




\begin{tabular}{|lr|}
\hline (a) Mendapat kiriman dari keluarga & $22,24 \%$ \\
(b) Negosiasi dengan petugas & $16,66 \%$ \\
(c) Pinjam-meminjam dengan sesama narapidana & $5,55 \%$ \\
(d) Kombinasi a + b & $38,88 \%$ \\
(e) Kombinasi a + c & $5,55 \%$, \\
(f) Kombinasi b + c & $5,55 \%$, \\
(g) Kombinasi a + b + c & $5,55 \%$. \\
\hline
\end{tabular}

Dari fakta lapangan yang terungkap dalam beberapa kali dilaksanakan FGD, secara umum para napi merasakan kesulitan dalam memperoleh pembalut karena pembalut semuanya disuplai dari pihak keluarga yang berkunjung. Bila napi tidak memiliki keluarga dekat yang berada dalam 1 (satu) kota yang sama (Kota Pekanbaru atau Bengkalis), mereka selalu mengalami kesulitan, padahal kebutuhan ini mereka perlukan setiap bulannya. Alternatif kedua adalah untuk membeli pembalut biasanya dapat dipesan pada sipir perempuan dan alternatif ketiga adalah membeli/meminjam pada napi lain dalam satu sel.

Sesungguhnya, pola ini sangat tergantung pada kedekatan dengan sesama napi. Namun karena adanya kelangkaan dan minimnya uang kontan diantara mereka menyebabkan mereka memiliki potensi konflik latent yang sangat tinggi berkaitan dengan langkanya pembalut wanita.

Jika uang kontan mereka terbatas, hal ini sering terjadi, maka muncul titik awal pemicu konflik diantara mereka, dan menjadi titik celah adanya pelanggaran HAM bagi para napi perempuan karena tidak terpenuhinya hak-hak kesehatan mereka.

Kunjungan dapat dilakukan setiap hari dalam jam-jam tertentu, tetapi berdasarkan fakta lapangan di LAPAS Anak/Wanita Klas II B Pekanbaru ada 2 pintu yang harus mereka lewati dan memang tidak ada tarif resmi tetapi ada tips yang harus mereka keluarkan atas dasar sukarela pada petugas jaga yang nota bene adalah petugas laki-laki. Ini menunjukkan bahwa kondisi LAPAS seringkali tidak sesuai dengan tataran ideal dan seringkali berbeda dengan realitasnya. Keadaan LAPAS di Propinsi Riau, pada umumnya masih jauh dari ideal yang harapkan. Saat ini, kehidupan dalam LAPAS masih diliputi kesemrautan disana-sini. Alih-alih terjadi interaksi edukatif, yang banyak ditemukan di dalam LAPAS justru kehidupan sebaliknya. LAPAS masih dikotori dengan segala macam praktik tak terpuji, seperti perlakuan diskriminatif, penyuapan, dan pemerasan. Akibatnya, LAPAS yang harusnya lebih berfungsi sebagai lembaga pendidikan dan penyadaran kini masih cenderung sebagai Sekolah Tinggi Tindak Kriminal. 


\section{Penyakit Infeksi}

Penyakit-penyakit kesehatan reproduksi yang sering dialami para napi perempuan adalah: (1) Keputihan; dan (2) Nyeri haid. Keluhan berobat mereka sampaikan pada poliklinik di LAPAS yang buka pada pukul 09.00 - 12.00 WIB. Di dalam setiap Lembaga Pemasyarakatan terdapat poliklinik, seorang dokter dan perawat yang bertugas serta obatobatan cukup tersedia. Jika narapidana membutuhkan obat di luar obatobatan yang disediakan maka narapidana yang bersangkutan akan dibantu oleh petugas Lembaga Pemasyarakatan untuk dibelikan sesuai permintaan dan kesanggupannya.

Adapun kecukupan makanan disediakan sesuai dengan kalori yang ditetapkan di dalam peraturan yang berlaku. Dalam kesempatan observasi, peneliti melihat contoh makanan yang disediakan bagi para narapidana dan peneliti menilainya sebagai cukup memadai. Lembaga Pemasyarakatan yang diteliti juga telah membuat daftar menu harian bagi narapidana. Demikian juga air minum selalu tersedia dengan baik.

\section{Pemenuhan Hak Kesehatan untuk Napi Perempuan}

Napi perempuan dan lak-laki memiliki akses layanan kesehatan yang setara. Meskipun demikian, hal ini tidak hanya berarti memperlakukan semua orang secara sama. Pendekatan seperti itu mengabaikan perbedaan-perbedaan biologis dan sosial. Perempuan memiliki sistem kerja tubuh yang berbeda dengan pria, susunan genetika yang berbeda, pengaruh hormon dan pola-pola peran berbasis jender, dan menderita penyakit-penyakit yang relatif berbeda pula. Karenanya, kebebasan untuk mengendalikan tubuh bagi perempuan merupakan suatu unsur yang penting bagi hak perempuan atas kesehatan, terutama pada akses kesehatan reproduksi yang sama sekali tidak dimiliki oleh napi laki-laki. Perempuan memerlukan perlakuan yang berbeda atas keunikan pada kondisi kesehatan reproduksi tersebut.

Harus diakui masih ada sinyalemen yang menganggap bahwa di dalam LAPAS masih tersisa bentuk diskriminasi terhadap napi perempuan, baik langsung (sengaja dirancang untuk memperlakukan perempuan secara berbeda) atau pun diskriminasi tidak langsung yang merupakan akibat dari apa yang kelihatannya sebagai netral namun mempunyai dampak diskriminatif terhadap perempuan, walaupun tidak dimaksudkan sebagai tindak diskriminasi. Dengan demikian, maka standar laki-laki diterapkan terhadap perempuan, suatu standar yang 
tidak memungkinkan atau menghilangkan hak perempuan untuk memperoleh kesempatan sama.

Dalam hal ini, maka negara (LAPAS) memiliki kewajibankewajiban yang penting sehubungan dengan penanganan HAM napi perempuan terkait dengan kesehatan reproduksi mereka, terutama dalam hal: (1) Menghapuskan praktek-praktek diskriminasi yang dilakukan oleh perorangan maupun kelembagaan, (2) Mengambil langkah-langkah untuk memastikan bahwa narapidana memiliki hak dan dapat memperoleh akses atas hak-hak mereka.

Diskusi kedua membahas tentang kemungkinan solusi mengurangi pelanggaran HAM dan juga mempromosikan perlindungan hak-hak narapidana perempuan di dalam LAPAS. Untuk pelaksanaan diskusi tersebut, data lapangan yang dikumpulkan melalui teknik observasi dan wawancara mendalam diajukan dalam suatu pertemuan FGD. Jalannya diskusi diarahkan dengan mengisi tiga kolom yang secara logika menggiring peserta FGD ke arah pemecahan masalah. Tiga kolom utama itu adalah keterbatasan LAPAS yang bisa mengakibatkan pelanggaran HAM; potensi pelanggaran HAM untuk kesehatan; dan upaya pemecahan yang diajukan. Penjelasan isi kolom-kolom tersebut dijabarkan berikut ini.

\section{Keterbatasan LAPAS dan potensi pelanggaran HAM}

Kegiatan Focal Group Discussion (FGD) dengan narapidana, petugas, dan dengan beberapa narasumber di dua lokasi LAPAS dihasilkan beberapa kendala yang masih dihadapi, yang jika tidak dilakukan solusi terhadapnya akan mengganggu upaya peningkatan perlindungan Hak Asasi Manusia (HAM) bagi narapidana perempuan. Kendala tersebut sebagian besar merupakan keterbatasan LAPAS yang meliputi (1) fasilitas fisik, (2) petugas medis, (c) petugas LAPAS

Kendala fasilitas fisik meliputi; (a) LAPAS narapidana perempuan tidak didukung oleh blok yang sepantasnya, dari persepsi HAM. Kenyataaannya, mereka ditempatkan dalam satu area dimana blok napi perempuan dan napi laki-laki dipisahkan hanya dengan kawat tinggi. Berdasarkan persepsi HAM, hal ini dinilai riskan dari segi keamanan dan dari terjadinya pelanggaran HAM; (b) Dua lokasi LAPAS (Pekanbaru dan Bengkalis) yang ada saat ini melebihi daya tampung atau over capacity dibandingkan dengan luas yang wajar. Kondisi over capacity ini mengakibatkan keterbatasan gerak ruang beraktivitas dan berinteraksi secara social, serta dapat memicu kesulitan dalam pengawasan dan pembinaan dan semakin memperkecil upaya perlindungan terhadap napi 
perempuan; (c) Masih minimnya pemenuhan sarana dan prasarana kesehatan dan kebersihan bagi narapidana perempuan menyebabkan mereka rawan terhadap berbagai masalah kesehatan reproduksi mereka.

Kendala dari petugas medis yaitu tidak tersedia petugas medis, khususnya di bidang narkoba, dan tenaga konselor (psikolog). Berdasarkan fakta lapangan, sebagian besar rutinitas di LAPAS menyebabkan mereka mengalami stres dan jenuh. Mereka butuh teman berbagi dan mencurahkan emosi dan perasaannya. Sementara kendala dari petugas LAPAS meliputi; (a) tingkat pemahaman HAM yang masih rendah bagi kebanyakan petugas LAPAS, dan kurangnya sosialisasi yang bermakna tentang pentignya perlindungan HAM bagi narapidana perempuan; (b) belum adanya budaya melayani, khususnya tugas di bidang pelayanan perlindungan HAM bagi narapidana perempuan akibat tugas rangkap; (c) kesejahteraan petugas LAPAS yang relatif kurang memadai menimbulkan upaya mencari penghasilan tambahan sehingga memicu timbulnya aksi korupsi.

\section{Potensi pelanggaran HAM kesehatan Napi Perempuan}

Berdasarkan narasi yang dituangkan di atas tentang keterbatasan LAPAS, hal itu memungkinkan napi perempuan berada pada posisi tawar-menawar yang rendah, sebagaimana digambarkan pada catatan berikut ini. (1) Sulit memperoleh Hak Kesehatan seperti kesulitan mendapatkan pembalut wanita merupakan satu contoh gambaran pelaksanaan Hak Kesehatan. Sebagian besar pembalut diperoleh dari keluarga yang berkunjung secara reguler. Mereka yang tidak dikunjungi oleh keluarga, mereka terpaksa menggunakan bahan seadanya yang jauh dari syarat higienitas, bahkan lebih jauh lagi menjadi rawan berpotensi buruk bagi kesehatan reproduksi perempuan. (2) Karena tidak ada mekanisme yang sederhana untuk mendaptkan kebutuhan pembalut tersebut, hal ini menimbulkan ketergantungan dalam pola pinjammeminjam alat pembalut, sehingga berpotensi memicu konflik antar sesama napi perempuan. Tidak jauh berbeda dengan adanya jasa penitipan untuk pembelian kebutuhan perempuan berpotensi memicu hubungan yang tidak seimbang antara napi dengan sipir atau antara napi dengan pihak keluarga napi lain yang dititipi. Karena hukum ekonomi tentang supply and demand berlaku disini.

Lebih dari itu, sistem yang berlaku di dalam LAPAS juga menimbulkan potensi pelanggaran HAM, seperti: (1) LAPAS dengan sistem penggabungan antara LAPAS perempuan dengan LAPAS anak, dan minimnya petugas LAPAS menimbulkan dampak negatif. 
Kebanyakan napi perempuan tidak berpakaian secara sopan, baju yang seadanya, pendek dan perilaku yang tidak patut dijadikan contoh bagi anak/anak remaja. (2) terbatasnya jumlah petugas LAPAS perempuan menyebabkan posisi tawar-menawar yang rendah bagi napi perempuan, terutama dalam mendapatkan hak kesehatan. (3) kebutuhan alat-alat mandi, alat mencuci, mencuci pakaian, dan alat untuk kebersihan ruangan yang sangat minim. Akibatnya mengesankan kamar (terutama untuk keperluan Mandi Cuci Kakus - MCK) berbau pengap; dan pakaian yang dicuci ala kadar nya menyebabkan mereka juga rawan dihinggapi berbagai jenis penyakit.

\section{Upaya mengurangi pelanggaran HAM Napi Perempuan}

Dari fenomena, hasil kajian dari FGD, dan mencermati sejumlah kendala, berikut ini intisari hal-hal yang perlu diupayakan sebagai bentuk tindakan mengurangi pelanggaran HAM Napi Perempuan: (1) melaksanakan capacity building, bagi petugas LAPAS, melalui pelatihan HAM dan sanksi serta penegakan aturan yang konsisten bagi petugas LAPAS, (2) membuat dan menetapkan standarisasi pemenuhan HAM yang jelas untuk narapidana, (3) membangun tingkat koordinasi yang solid antar lembaga penegak hukum maupun dengan lembaga-lembaga lain yang bertanggung jawab terhadap perlindungan dan pemenuhan HAM bagi narapidana dan kerjasama antar pihak terkait, antara lain; Kanwil Departemen Hukum dan HAM, Kanwil Deparetemen Agama, Dinas Pendidikan Nasional, Dinas Kesehatan, Kepolisian, Persekutuan Gereja, Pemerintah Provinsi Riau, dan Universitas Riau, dan instansi terkait lainnya, (4) menerapkan sistem monitoring dan evaluasi terhadap pemenuhan HAM bagi narapidana di LAPAS, (5) penambahan anggaran untuk penyediaan sarana dan prasarana, bila perlu pembuatan LAPAS khusus wanita di setiap kota di Provinsi Riau, dan petugas sipir perempuan yang berkualifikasi.

\section{SIMPULAN}

Terkait hak pemenuhan akses kesehatan (reproduksi) yang masih sangat memprihatinkan sehingga mengindikasikan adanya sejumlah pelanggaran HAM bagi napi perempuan, seperti pengabaian faktor sosial psikologis dan pengabaian kodrat perempuan (siklus haid) dan dalam mendapatkan akses kesehatan, LAPAS khusus napi perempuan, menurut perspektif HAM belum tersedia di Kota Pekanbaru dan Kabupaten Bengkalis. LAPAS yang saat ini ditempati oleh napi perempuan masih memprihatinkan, tidak memadai secara fisik, sarana MCK, dari segi 
higienitas dan medis, tidak menjamin keamanan. Semuanya berkontribusi terhadap pelanggaran HAM

Upaya mengurangi pelanggaran HAM terhadap napi perempuan dapat dilakukan dengan: Membangun capacity building bagi petugas LAPAS; Menetapkan standarisasi yang jelas tentang pemenuhan HAM bagi napi perempuan sekaligus mengimplementasikan sistem evaluasi dan monitoring yang berhubungan dengan kemudahan kinerja petugas LAPAS. Juga dinilai penting, membangun tingkat koordinasi antar lembaga penegak hukum terkait. Kesimpulan dan saran terakhir adalah meningkatkan anggaran untuk merenovasi dan perawatan sarana fisik.

\section{Endnotes}

1 Muhammad Adib, Kenakalan dan Perilaku Seksual Remaja Perkotaan, dalam Masyarakat, Kebudayaan dan politik, FISIP Universitas Airlangga no. 03-04, Vol. VII, Mei-Juli 1993, hlm 59.

2 Kompas, 19 Pebruari 2003, hlm 10.

3 Basic Principles for the Treatment of Prisoners, Adopted and proclaimed by General Assembly resolution 45/111 of 14 December 1990, article 1 (All prisoners shall be treated with the respect due to their inherent dignity and value as human beings).

${ }^{4}$ Suprapti, Ratna, Menopause dilalui sebagian besar perempuan, Suara Pembaruan, 16 Maret 2003,

5 Basic Principles for the Treatment of Prisoners, Adopted and proclaimed by General Assembly resolution 45/111 of 14 December 1990, article 3 (desirable to respect the religious beliefs and cultural precepts of the group to which prisoners belong, whenever local conditions so require).

\section{DAFTAR PUSTAKA}

Akbar, Sofwan. 2008. Pembinaan Narapidana Penyalahgunaan Narkoba di Rumah Tahanan Negara Klas II B Siak Sri Indrapura. Skripsi tidak diterbitkan. Pekanbaru: Sosiologi FISIP Universitas Riau.

Anonim. 1998. Memasuki Sebuah Dunia Baru Kehidupan Seksual Dan Reproduksi Perempuan Muda. Jakarta: The Allan Guttmacher Institute.

Baker, Saskia dan Hansje Plagman. 2006. Instrumen Kajian Hak-Hak Kesehatan Perempuan, Humanist Committee on Human Rights (AIM FOR HUMAN RIGHTS)

Direktorat Jenderal Pemasyarakatan Departemen Hukum dan HAM RI.2008. Praktik-Praktik Penyiksaan Dan Perlakuan Yang Tidak 
Menyenangkan Di Dalam Lapas/Rutan. Disampaikan dalam Lokakarya Nasional HAM, Jakarta.

Eide, Asbjorn dan Catarina Crause. t.th. Hak Ekonomi Sosial dan Budaya, Buku Teks Pustaka Hak Azasi Manusia Raoul Wallenberg Institute.

Heribertus Sutopo. 1988. Pengantar Penelitian Kualitatif. Surakarta: Pusat Penelitian UNS.

Kompas, 19 Pebruari 2003, hlm 10.

Lapas Bengkalis. 2008. Rencana Kerja, Program Kerja dan Kalender Kerja Lapas Bengkalis.

Mattew B. Milles dan Michael Huberman. 1990. Qualitatif Data Analisis, terjemahan Tjetjep Rohendi. Jakarta: UI Press,

Muhamad Adib. 1993. Kenakalan dan Perilaku Seksual Remaja Perkotaan. Jurnal Masyarakat, Kebudayaan dan Politik. FISIP Universitas Airlangga No.03-04, Vol.VII, Mei-Juli.

Ratna Suprapti. 2003. Menopause Dilalui Sebagian Besar Perempuan. Koran Suara Pembaruan. 16 Maret.

PBB, Basic Principles for the Treatment of Prisoners, Adopted and proclaimed by General Assembly resolution 45/111 of 14 December 1990, article 1 (All prisoners shall be treated with the respect due to their inherent dignity and value as human beings).

Undang-undang RI No 12 tahun 1995 tentang Sistem Pemasyarakatan, Pasal 14 (ayat I), mengamanatkan jaminan hak-hak para narapidana. 